Gut, 1984, 25, 925-930

\title{
Early organogenesis of human small intestine: scanning electron microscopy and brush border enzymology
}

\author{
B LACROIX, M KEDINGER, P SIMON-ASSMANN, AND K HAFFEN \\ From the Unité de Recherches de Physiopathologie Digestive, Unité 61, INSERM, Strasbourg, France
}

SUMMARY Human small bowel early organogenesis was studied by scanning electron microscopy and found to be correlated to brush border enzymology. The appearance of the brush border enzymes sucrase, lactase, and aminopeptidase (measured in a purified apical membrane fraction) coincides with the first outgrowth of villi (eight weeks). Alkaline phosphatase was detected at seven weeks. The content of these enzymes furthermore increased up to the 14th week when both sucrase and aminopeptidase activities were comparable with adult values.

The maturation events occurring during ontogenesis of the gut and the factors involved in their control have been mainly studied in rodents. ${ }^{1-3}$ In spite of data $^{4-7}$ which emphasised the precocious morphological ${ }^{5-10}$ and especially enzymatic maturation ${ }^{511-14}$ in the course of human intestinal development, the precise onset of brush border enzyme function in the small intestine needed to be defined.

The purpose of the present study was to reinvestigate the early enzymatic maturation of the human small intestine as a function of distinct morphological events. Such an investigation was considered important for the following reasons: precise anatomical guide markers of early foetal age based on hand morphology are now available; ${ }^{15}$ enzyme determination of human foetal gut had never been performed on purified brush border membranes; scanning electron microscopic observations of early human gut organogenesis are lacking; and lastly, this information is vital for follow up in vitro studies on the mechanisms underlying enzyme synthesis in human foetal gut, like those performed in rodents. ${ }^{16-21}$

\section{Methods}

MATERIAL

Foetal human intestine

Foetal human intestine was obtained between 7 and 14 and at the 22nd week of gestation after legal or

Address for correspondence: Dr B Lacroix, Unité de Recherches de Physiopathologie Digestive, U61, INSERM, 3 Avenue Molière, Strasbourg, France.

Received for publication 25 November 1983 therapeutic-induced abortions with the informed consent of the mothers. The abortion material was kept at $4^{\circ} \mathrm{C}$ for two to 24 hours in Ham F10 tissue culture medium until organ removal; only healthy and undamaged intestinal tracts were used. Foetal age was determined by the developmental pattern of hand morphology. ${ }^{15}$

\section{Adult human intestinal mucosa}

Jejunum was obtained from surgical resections by the method reported by Hauri et al $l^{22}$ and Kedinger et al. ${ }^{23}$ Distal ileum was obtained from irreversibly brain damaged kidney donors provided by the French association 'France-Transplant' ${ }^{24}$ Hôpital St Louis-Pavilon Lugol 2, pl. du Docteur Fournier, Paris.

\section{SCANNING ELECTRON MICROSCOPY}

Small bowel specimens were fixed in $0.2 \mathrm{M}$ cacodylate buffered $2 \%$ glutaraldehyde $(\mathrm{pH} \mathrm{7.4)}$ at $4^{\circ} \mathrm{C}$. They were then dehydrated, dried in a critical point drier (Balzers Union) and coated with gold, using a sputter coater (Balzers Union). The specimens were examined with a Philips 501 B scanning electron microscope.

\section{ENZYMATIC ANALYSIS}

Enzyme determinations were made on segments (weighing at least $3 \mathrm{mg}$ ) along the length of the entire foetus small intestine (maximum age, 14 weeks). For the adult studies, jejunum and ileum fragments weighing approximately $20 \mathrm{mg}$ were used. The gut samples were kept frozen at $-80^{\circ} \mathrm{C}$ until homogenisation, purification of brush border membranes $^{25}$ and enzyme determinations. Sucrase 
activity was assayed according to Messer and Dahlqvist ${ }^{26}$ lactase according to Koldovsky et al, ${ }^{27}$ alkaline phosphatase according to Garen and Levinthal, ${ }^{28}$ and aminopeptidase according to Maroux et al. ${ }^{29}$ Proteins were assayed by the method of Lowry et al.$^{30}$ All enzyme activities are expressed as milliunits per milligram of protein: one unit is defined as the activity that hydrolyzes $1 \mu$ mole of substrate/min under the experimental conditions. The number of individual foetal intestines analysed enzymatically was respectively $3,6,3,3,4,4,1$ and again 1 for the $7,8,9,10,11,12,14$ and $22^{*}$ week specimens. Fragments of jejunum and ileum were analysed from respectively six and 21 adult patients.

\section{STATISTICAL ANALYSIS}

Results are expressed as the mean \pm SEM. Student's $t$ test was used to analyse the data for statistical significance of differences between means. Differences with a $p$ value of less than 0.05 were considered to be significant.

\section{Results}

\section{A MORPHOLOGICAL STUDY}

A gradual increase in small bowel length was observed between the 7 th and 14th week of gestation (Fig. 1). The major age related changes in the surface features of the duodenum are illustrated in Fig. 2. The luminal side of the intestinal tube remains flat until the eighth week which is the stage at which the villi first appear as rounded projections (Fig. 2a). The apical layer of cells exhibits short and very irregular microvillus-like formations (Fig. 2f). At nine weeks, the villi are more obviously arranged along longitudinal ridges which are separated by lines of regularly disposed crypt mouths (Fig. 2b). Between the 10th and 14th weeks, the villi progressively increase in height and acquire a typical finger shaped aspect (Figs. 2c and d); the apical brush borders are composed of regular microvilli (Fig. $2 \mathrm{~g}$ ) which are similar to those found in the adult intestine. Figure $2 \mathrm{e}$ illustrates the adult duodenal mucosa composed of convoluted villi. These main events in villus and microvillus morphogenesis are corroborated by the histology and transmission electron microscopy studies performed by both ourselves as well as by other authors. ${ }^{5} 10$

The proximodistal gradient of villus morphogenesis is particularly clear at the scanning electron microscopic level at 11 weeks, which is the moment when the precaecal region just starts to form protuberances (Fig. 3b). The most proximal part meanwhile displays well formed villi (Fig. 3a).

* Anencephalic foetus

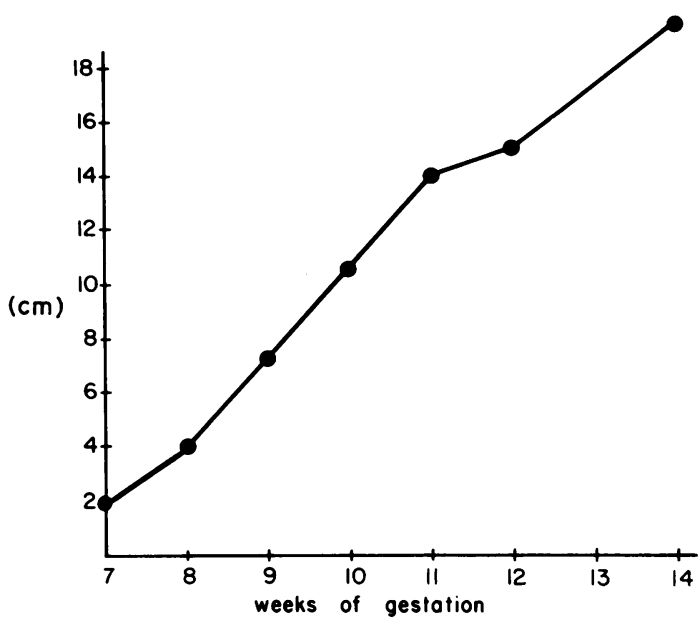

Fig. 1 Length of the small intestine extending from the pylorus to caecum as function of foetal age.

B ENZYMATIC ANALYSIS

At seven weeks of gestation, sucrase activity (Fig. 4) is undetectable. From eight weeks onwards, its activity increases progressively until 14 weeks $(p<0.001$ from one week to the next). The amounts present at this developmental stage are not significantly different from those present in the adult jejunum or ileum. No further marked changes occur thereafter (assays performed during mid and late gestation - that is, 20 to 36 weeks, not illustrated), although individual variations are more important than between eight and 14 weeks of foetal life. Higher amounts of enzyme activity were observed in the proximal than in the distal part, at eight and nine weeks, reflecting the maturation process. At 10 weeks and onwards, the main proximodistal differences foreshadow the adult pattern of sucrase activity differences between the jejunum and ileum.

Low levels of lactase activity (Fig. 4) are detectable in the proximal but not distal parts of the intestine at eight and nine weeks. At later stages, when lactase is present all along the small intestine, no clear cut gradient is visible. Lactase activity is low up till 12 weeks and increases significantly $(\mathrm{p}<0.001)$ at 14 weeks, but even then it remains far lower than at term $(305.6 \pm 33.4 \mathrm{mU} / \mathrm{mg}$ prot $)$ or in the adult jejunum $(\mathrm{p}<0 \cdot 001)$.

The quantitative development of aminopeptidase (Fig. 5) is very comparable with that reported for sucrase. It becomes detectable at eight weeks, thereafter increases progressively $(p<0.001)$ until 11-12 weeks and more abruptly at 14 weeks $(p<0.001)$, at which point the levels of its activity 

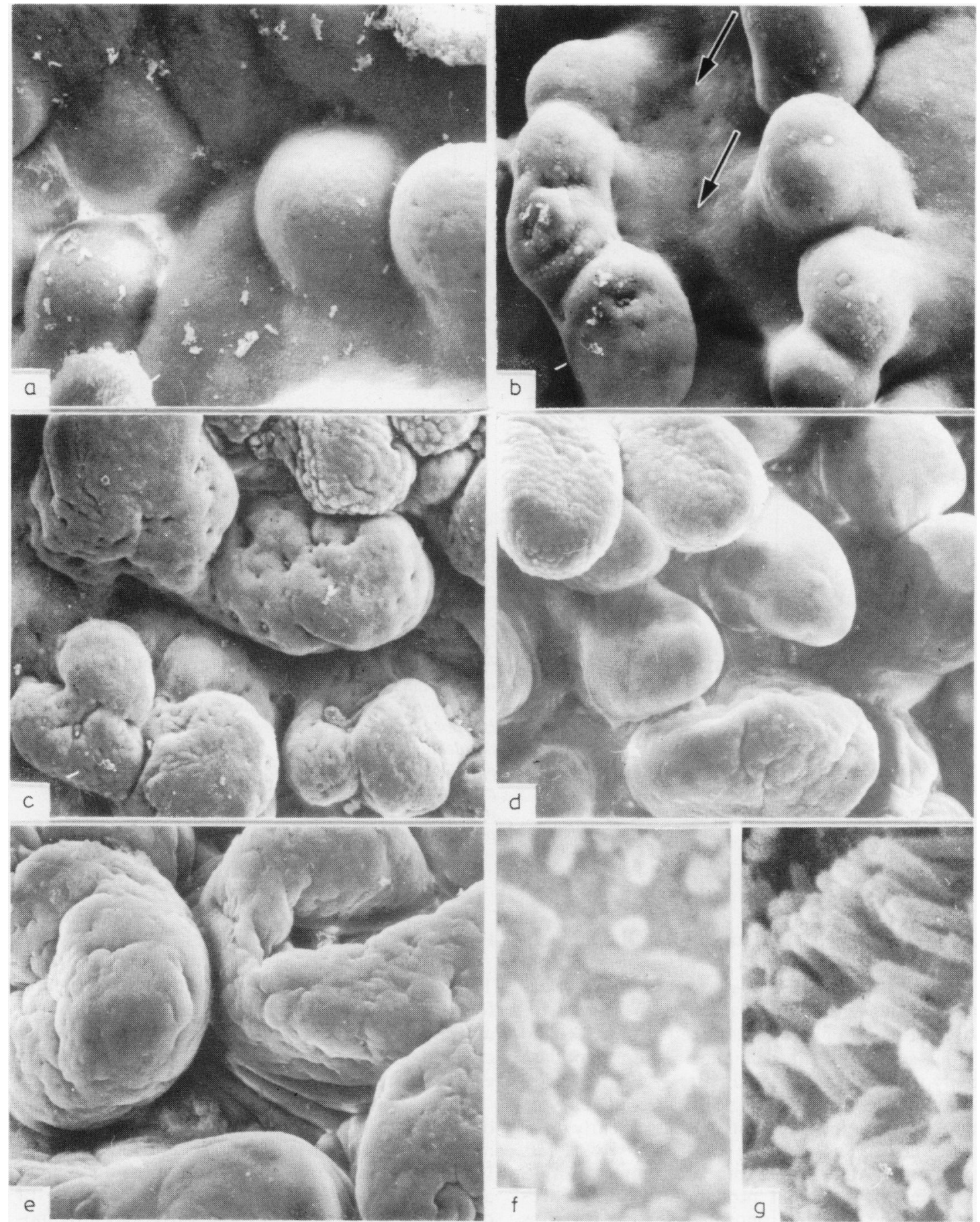

Fig. 2 Scanning electron microscopic aspect of duodenal luminal surface at $8(a), 9(b), 11(c), 14$ (d) weeks of gestation and in the adult (e). (Original magnification: $\times 320)$. Higher magnification of the apical microvilli at $8(f)$ and $14(g)$ weeks (original magnification: $\times 20000$ ). Arrows indicate a line of crypt mouths. 


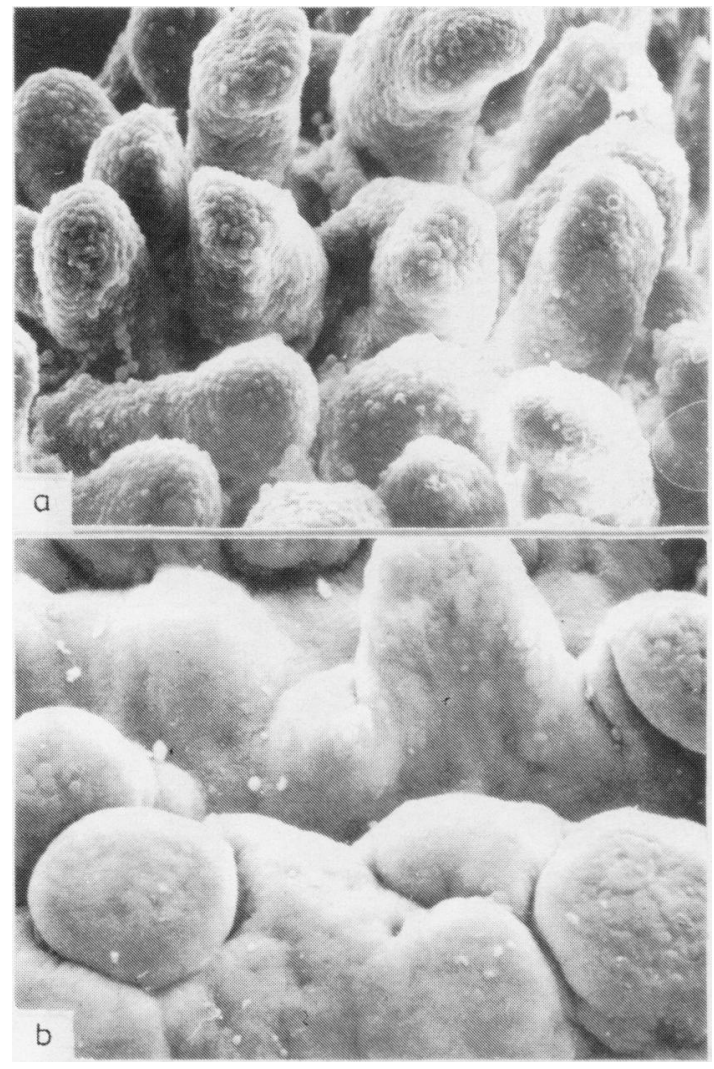

Fig. 3 Scanning electron microscopic aspect of luminal surface of an 11 week old foetal intestine: a: proximal duodenum; b: precaecal region. (Original magnification: $\times 320)$.

are those of the adult intestine. From the moment aminopeptidase is present in the foetal intestine and until nine to 10 weeks, one observes a clear proximodistal gradient of maturation. Its distribution is thereafter inversed; indeed at 14 weeks and in the adult intestine, highest aminopeptidase activity is found in the distal part.

Alkaline phosphatase (Fig.5) is the only enzyme which is present in significant amounts as early on as seven weeks. The increase of its activity is less marked than that of the other enzymes until 12 weeks and no apparent proximodistal differences are obvious. Alkaline phosphatase activity rises abruptly at 14 weeks $(p<0.001)$, the levels remaining, however, far lower than those of late gestation $(3518 \cdot 2 \pm 443.1 \mathrm{mU} / \mathrm{mg}$ prot $)$ or of the adult intestine $(\mathrm{p}<0 \cdot 001)$.

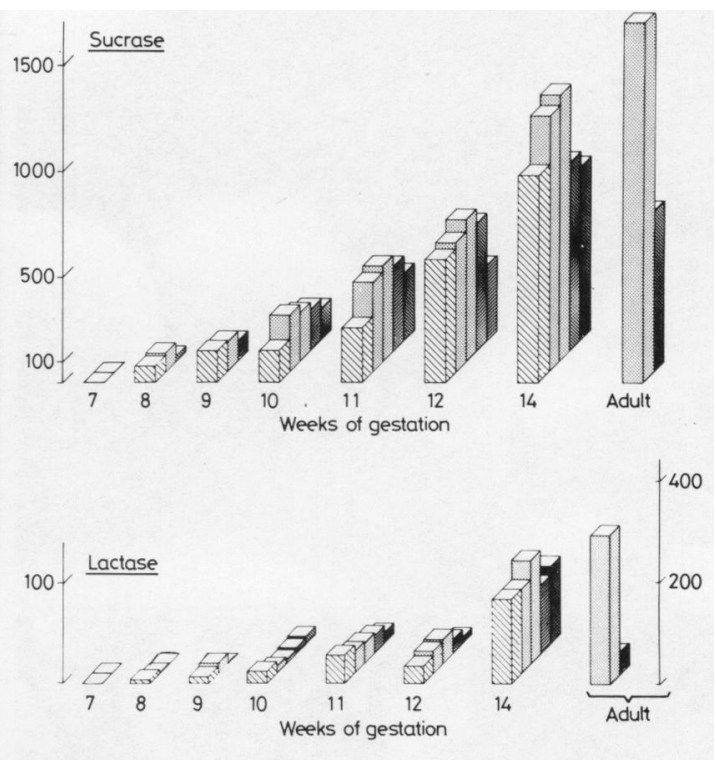

Fig. 4 Sucrase and lactase activities expressed in $\mathrm{mU} / \mathrm{mg}$ brush border proteins as a function of age and their

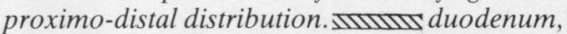
proximal and distal jejunum, wallat proximal and distal ileum. Small bowel of the youngest foetuses were subdivided into two or three parts. From the 10th week onwards, the whole small intestine was divided into five to 20 segments, which were assayed separately and reported as follows: the first postgastric and the last precaecal segments (presumptive duodenum and distal ileum: 1st and 5th columns) were plotted separately, whereas the intermediate segments were pooled into three groups corresponding respectively to the presumptive proximal and distal jejunum and to the proximal ileum (2nd, $3 r d$ and 4 th columns).

\section{Discussion}

The present study uses a new method of dating early foetal age with accuracy, namely, on the basis of the morphological features of the hand. ${ }^{15}$ This approach enabled a perfect linear curve relationship to be established between intestinal length and real age.

The second novelty of the present study is the demonstration of a clear parallelism between morphological and enzymatic differentiation. Indeed, the first outgrowth of villi in the duodenum at eight weeks coincides with the appearance of digestive enzyme activities. Similarly, the proximodistal morphological maturation is paralleled by a proximodistal appearance of enzyme activities which is particularly marked for lactase and aminopeptidase at the earliest stages. 

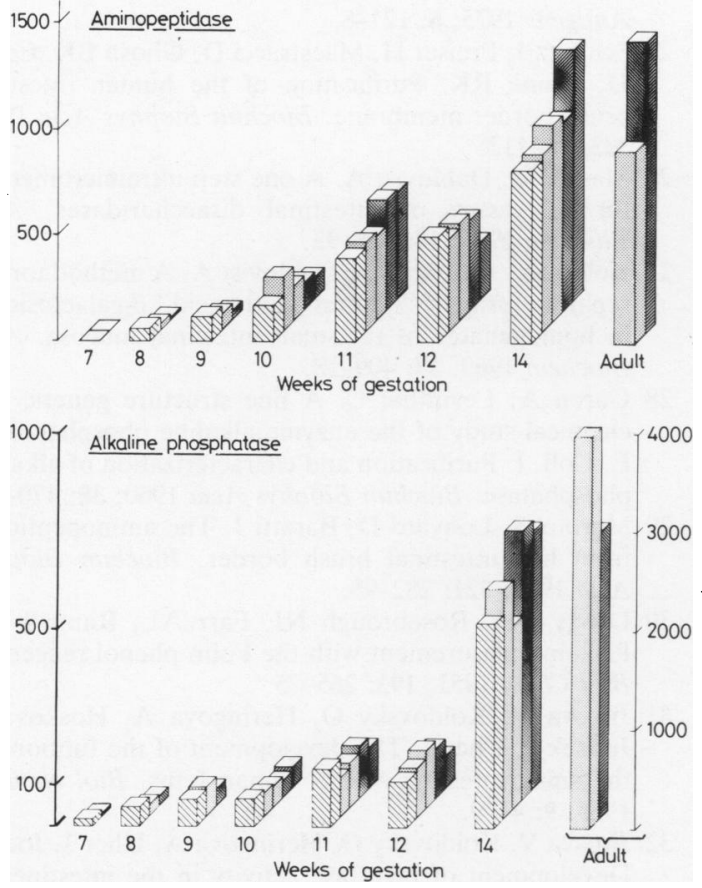

Fig. 5 Aminopeptidase and alkaline phosphatase activities. proximal and distal jejunum, proximal and distal ileum. Details are the same as in Fig. 4.

Our results further confirm and define the existence of a proximodistal distribution of enzyme activities in the foetal intestine ${ }^{12-143132}$ which resembles the adult pattern. ${ }^{33}{ }^{34}$ Our data on the evolution of the different enzymes between the 8th and 14th week are somewhat at variance with previous studies. ${ }^{121435}$ These discrepancies could be because of erroneous assessments of foetal ages and/or to the differences in the technical approach used - that is, determining enzyme activities in purified brush border membranes rather than in whole homogenates increases the assay sensitivity considerably. Purification of sucrase activity is thus enhanced three or 10 fold, depending on the maturation state of the brush border membrane itself. This is less dense at eight or nine weeks than between 10 and 14 weeks of gestation.

A further interesting finding is the significant reduction in specific enzyme activities in a 22 week old anencephalic foetus (mean activities in the whole intestine: sucrase: 300 ; lactase: 20 ; aminopeptidase: $291 \mathrm{mU} / \mathrm{mg}$ prot); alkaline phosphatase was less affected $(404 \mathrm{mU} / \mathrm{mg}$ prot). These data raise the problem of the role of glucocorticoids in the functional maturation of the human gut, as it is known that high amounts of corticosterone sulphate are produced by the human foetus and moreover that the concentration of this corticoid is significantly lower in the plasma of mothers carrying anencephalic foetuses. ${ }^{36}$ Although, no data on the control of human intestinal enzyme synthesis in the course of development are available, there is considerable evidence for the direct involvement of glucocorticoids in the ontogenesis of the small intestine in rodents. ${ }^{1620}$

The authors would like to thank E Alexandre, D Daviaud, and F Gossé for their excellent technical assistance. Drs A Zweibaum, B Kern, and their collaborators are greatly acknowledged for support and interest in this work and Dr E Krug for help with the text. Financial support was obtained from the INSERM and CNRS.

\section{References}

1 Moog F. Endocrine influences of the functional differentiation of the small intestine. J Anim Sci 1979; 49: $239-49$.

2 Henning SJ. Postnatal development: coordination of feeding, digestion and metabolism. Am J Physiol 1981; 241: G199-214.

3 Moog F. Induction of brush border enzymes in organ culture. J Pediatr Gastroenterol Nutr 1982; 1: 161-2.

4 Koldovsky O. In: Development of the functions of the small intestine in mammals and man. Basel: Karger, 1969: 27.

5 Grand RJ, Watkins JB, Torti FM. Development of the human gastrointestinal tract. Gastroenterology 1976; 70: $790-810$

6 Shmerling DH. Development of digestive and absorptive function in the human fetus. Nutr Metabol 1976; 20: 76-9.

7 Schmitz J, Triadou N, Rey J. Développement des fonctions digestives et des mécanismes de régulation de l'appétit. Gastroentérol Clin Biol 1978; 2: 929-40.

8 Kelley RO. An ultrastructural and cytochemical study of developing small intestine in man. J Embryol Exp Morphol 1973; 29: 411-30.

9 Moxey PC, Trier JS. Specialized cell types in the human fetal small intestine. Anat Rec 1978; 191: 269-85.

10 Moxey PC, Trier JS. Development of villus absorptive cells in the human fetal small intestine: a morphological and morphometric study. Anat Rec 1979; 195: 463-82.

11 Lev R, Siegel HI, Bartman J. Histochemical studies of developing human fetal small intestine. Histochemie 1972; 29: 103-19.

12 Antonowicz I, Chang SK, Grand RJ. Development and distribution of lysosomal enzymes and disaccharidases in human fetal intestine. Gastroenterology 1974; 67: 51-8. 
13 Antonowicz I, Lebenthal E. Developmental pattern of small intestinal enterokinase and disaccharidase activities in the human fetus. Gastroenterology 1977; 72: 1299-1303.

14 Auricchio S, Stellato A, Devizia B. Development of brush border peptidases in human and rat small intestine during fetal and neonatal life. Pediatr Res 1981; 15: 991-5.

15 Lacroix B, Wolff-Quenot MJ, Haffen K. Early human hand morphology: an estimation of fetal age. Early Human Develop 1984; 9: 127-36.

16 Kedinger M, Simon PM, Raul F, Grenier JF, Haffen $\mathrm{K}$. The effect of dexamethasone on the development of rat intestinal brush-border enzymes in organ culture. Develop Biol 1980; 74: 9-21.

17 Haffen K, Kedinger M, Simon PM, Raul F. Organogenetic potentialities of rat intestinal epitheloid cell cultures. Differentiation 1981; 18: 97-103.

18 Kedinger M, Simon PM, Grenier JF, Haffen K. Role of epithelial-mesenchymal interactions in the ontogenesis of intestinal brush-border enzymes. Develop Biol 1981; 86: $339-47$.

19 Raul F, Kedinger M, Simon PM, Grenier JF, Haffen $\mathrm{K}$. Comparative in vivo and in vitro effect of mono and disaccharides on intestinal brush border enzyme activities in suckling rats. Biol Neonate 1981; 39: 200-7.

20 Simon-Assmann PM, Kedinger M, Grenier JF, Haffen $\mathrm{K}$. Control of brush border enzymes by dexamethasone in the fetal rat intestine cultured in vitro. $J$ Pediatr Gastroenterol Nutr 1982; 1: 257-65.

21 Haffen K, Lacroix B, Kedinger M, Simon-Assmann PM. Inductive properties of fibroblastic cell cultures derived from rat intestinal mucosa on epithelial differentiation. Differentiation 1983; 23: 226-33.

22 Hauri HP, Kedinger M, Haffen K, Freiburghaus A, Grenier JF, Hadorn B. Biosynthesis of brush border glycoproteins by human small intestinal mucosa in organ culture. Biochim Biophys Acta 1977; 467: 32739.

23 Kedinger M, Hauri HP, Haffen K, Green JR, Grenier JF, Hadorn B. Turnover studies of human intestinal brush border membrane glycoproteins in organ culture. Enzyme 1979; 24: 96-106.

24 Zweibaum A, Oriol R, Dausset J, Marcelli-Barge A, Ropartz C, Lanset S. Definition in man of a polymorphic system of the normal colonic secretions. Tissue
Antigens 1975; 6: 121-8.

25 Schmitz J, Preiser H, Maestracci D, Ghosh BK, Cerda JJ, Crane RK. Purification of the human intestinal brush border membrane. Biochim Biophys Acta 1973; 323: 98-112.

26 Messer M, Dahlqvist A. A one step ultramicromethod for the assay of intestinal disaccharidases. Anal Biochem 1966; 14: 376-92.

27 Koldovsky O, Asp NG, Dahlqvist A. A method for the separate assay of "neutral" and "acid" $\beta$-galactosidase in homogenates of rat small intestinal mucosa. Anal Biochem 1969; 27: 409-18.

28 Garen A, Levinthal C. A fine structure genetic and chemical study of the enzyme alkaline phosphatase of E. Coli. I. Purification and characterization of alkaline phosphatase. Biochim Biophys Acta 1960; 38: 470-83.

29 Maroux S, Louvard D, Baratti J. The aminopeptidase from hog intestinal brush border. Biochim Biophys Acta 1973; 321: 282-95.

30 Lowry OH, Rosebrough NJ, Farr AL, Randall RJ. Protein measurement with the Folin phenol reagent. $J$ Biol Chem 1951; 193: 265-75.

31 Jirosva V, Koldovsky O, Heringova A, Hoskova J, Jirasek $J$, Uher $J$. The development of the funtions of the small intestine of the human fetus. Biol Neonate 1965; 9: 44-9.

32 Jirosva V, Koldovsky O, Heringova A, Uher J, Jodl J. Development of invertase activity in the intestines of human fetuses, appearance of jejunoileal differences. Biol Neonate 1968; 13: 143-6.

33 Asp NG, Gudmand-Höyer E, Andersen B, Berg NO, Dahlqvist A. Distribution of disaccharidases, alkaline phosphatase and some intracellular enzymes along the human small intestine. Scand J Gastroenterol 1975; 10: 647-51.

34 Skovbjerg H. Immunoelectrophoretic studies of human-small intestinal brush border proteins - the longitudinal distribution of peptidases and disaccharidases. Clin Chim Acta 1981; 112: 205-12.

35 Dahlqvist A, Lindberg $T$. Development of the intestinal disaccharidase and alkaline phosphatase activities in the human foetus. Clin Sci 1966; 30: 517-28.

36 Fencl M de M, Stillman RJ, Cohen J, Tulchinsky D. Direct evidence of sudden rise in fetal corticoids late in human gestation. Nature 1980; 287: 225-6. 